\title{
Mining Memories: New Explorations in Cinema, Memory and the Past
}

\section{Editorial}

\section{Gwenda Young}

Jean-Luc Godard once observed of Bertrand Tavernier that they shared a common origin: as children of "the Libération and the Cinémathèque" they came of age in the turbulent 1960s (qtd. in A Journey Through French Cinema (Voyage à travers le cinéma français, Bertrand Tavernier, 2016)). Tavernier, who died in March of this year, is an appropriate filmmaker to commemorate in this Introduction to an issue of Alphaville dedicated to themes of memory and the past. In a career spanning seven decades, he produced work that investigated, appraised and revealed the role that the past-and what gets remembered and what gets forgotten - plays in the shaping of individual identity and collective culture.

In his 2016 documentary, A Journey Through French Cinema, Tavernier shared a memory of a seminal incident from his childhood:

my parents took me out to the terrace that overlooked Lyon. I was three years old, it was September '44. And I saw lots of flares lighting up the sky. They announced the entrance of troops liberating Lyon. American and French troops. All around me people were laughing and clapping. It was a festive atmosphere. And I've never forgotten that sight. I've never forgotten that light in the sky. And when I went to the cinema and suddenly light filled the screen and the curtain opened, I thought of the lights in the sky. The screen about to light up symbolised in a way the hope I sensed around me.

A vivid anecdote, recollecting a moment in which long years of dark trauma were eclipsedalbeit fleetingly — by the flares of the Libération, segues here into a remembrance of the joy of cinemagoing. This formative memory, related at the start of a documentary that offers a personal journey through the labyrinths of French cinema, contains revealing associations - of past and present, trauma and liberation, light and dark - that would go on to inform Tavernier's career as filmmaker, writer and advocate for film preservation. They underpin, too, the core considerations of the essays and the podcast that make up this Issue.

Tavernier's debut feature, The Clockmaker of St. Paul (L'Horloger de Saint-Paul, 1974), introduces themes and a sense of place that would resurface, in diverse iterations, throughout his career. Set in his hometown of Lyon, it follows the story of the ordinary and orderly clockmaker, Michel Descombes (Philippe Noiret), whose mundane routine is thrown into chaos when he learns that his son (Sylvain Rougerie) has been arrested for murder. There follows a quest to uncover the truth about his son's actions, one that prompts a journey into 
self and memory that forces him to confront uncomfortable truths about their fractured relationship and about the selective nature of individual memory and narratives of the past. The nuanced, poignant Descombes, executed by actor and director without sentimentality, anticipates later protagonists in some of Tavernier's most celebrated works: from the selfdestructive saxophonist (Dexter Gordon) of 'Round Midnight (1986), the elderly bourgeois artist (Louis Decreux) of $A$ Sunday in the Country (Un Dimanche à la campagne, 1984), the dying father (Dirk Bogarde) of Daddy Nostalgia (1990), each haunted by memories of youth and its vibrant potential; to the police detective (Didier Bezace) whose idealism is rapidly dwindling in a sea of bureaucracy and indifference in L.627 (1992); and the military man (Philippe Noiret) of Life and Nothing But (La Vie et rien d'autre, 1989), whose attempts to impose order on chaos, to number and identify the corpses recovered from the scarred landscape of France in 1920, merely reiterates to him the futility of the task and the impossibility of challenging the empty rhetoric of State.

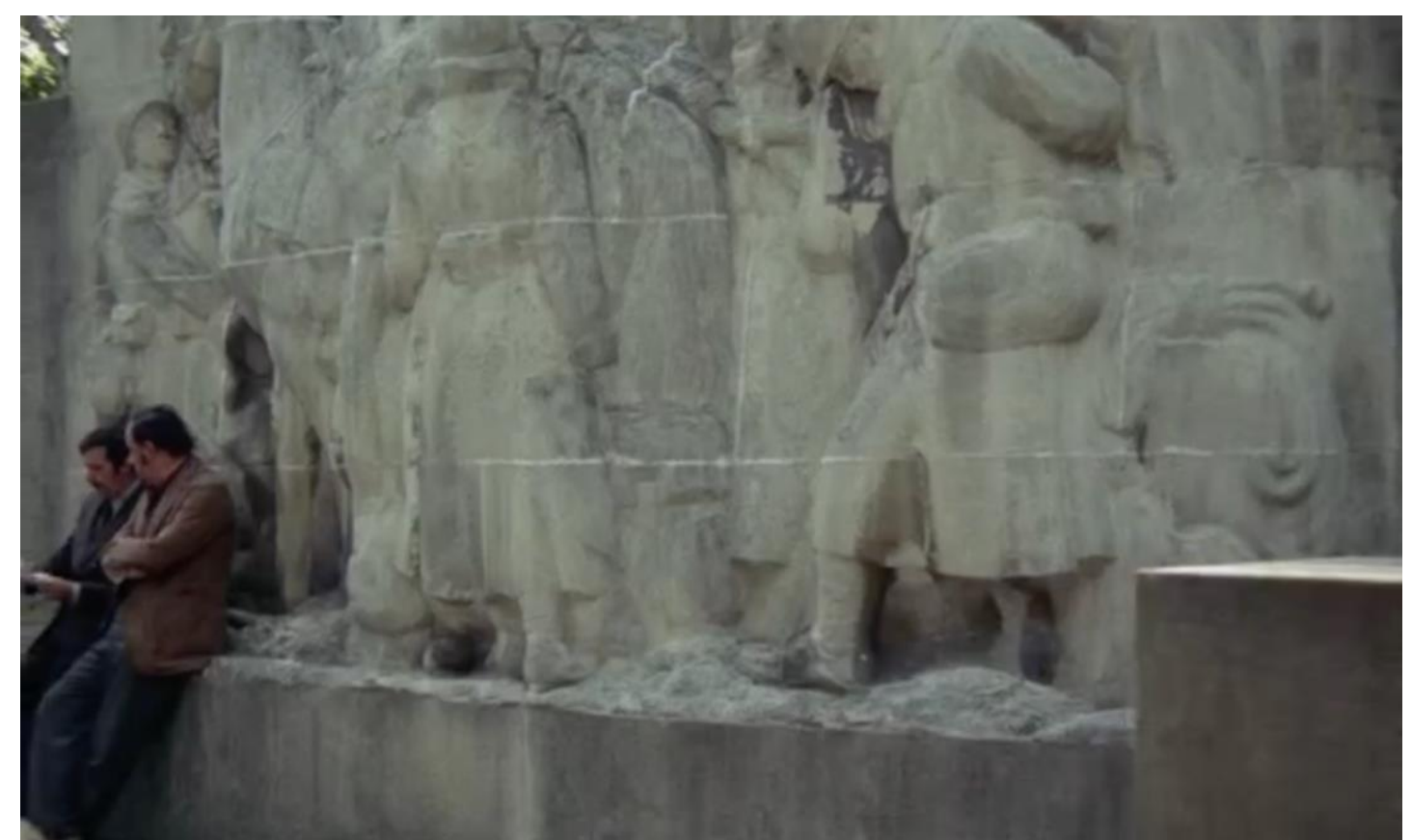

Figure 1: Descombes (Philippe Noiret) and Commissaire Guilboud (Jean Rochefort) meet to discuss the case. The Clockmaker of St. Paul (L'Horloger de Saint-Paul, Bertrand Tavernier, 1974). Lira Films, 1974. Screenshot.

Sites of memory dot Tavernier's landscapes - from brief glimpses of statues commemorating the "great men" of colonial Europe to war monuments dedicated to "les enfants" lost in the Great War. More often than not, these are used as backdrops for intense scenes in which his characters struggle to make sense of a present reality of confusing narratives and blurred recollections. This preoccupation is one he introduced early in his career: in The Clockmaker of St. Paul the protagonist's negotiation of a current traumatic event, which causes long-repressed memories of personal loss to resurface, serves to reflect the collective traumas, confusion and generational conflicts that seem to define postwar France (especially in the aftermath of 1968). The linking of the personal with the collective, expressed in thematic terms and executed using an aesthetic style favouring wide shots, two-shots and often highlymobile camerawork, signals Tavernier's auteur status (of a mode that locates him-at least in the sense of a shared interest in tackling diverse genres-to the American cinema he so admired). While his exploration of memory, individual and collective, can be seen in a great number of his films, it is most significant in the productions that deal with the subject of war 
and the slippages between the official accounts of patriotism and military "achievements", and the personal memories of those involved and those left behind. In his debut film, the clockmaker moves through a city filmed through the eye of an insider, a child of the Occupation and son of a member of the Resistance that used the back streets, forgotten quarters and nondescript buildings as sites of concealment, of flight, and of the dissemination of information. ${ }^{1}$ As Stephen Hay notes in an early study of the director's career, Tavernier tends to eschew landmark shots, typical of the "cinema touristique", in favour of shots that work to establish a "complex metaphysical relationship between character, environment and event" and that draw out "meaningful connections between the distant and recent past" (42).

In his prolific career as a film critic and historian — which predated his directing career and continued in tandem with it-Tavernier was less interested in reiterating established versions of film history or in proposing new hierarchies or pantheons, than in giving space to overlooked (sometimes unfashionable) films and filmmakers. An unwavering cinephilia, which coloured his approach to his filmmaking and film criticism, was one of the main motivators for his excavations of film history (however uncomfortable the truths uncovered might be to the Establishment). ${ }^{2}$ It influenced, too, his handling of films with historical themes or films set in earlier epochs. Those set in the distant past, such as Let Joy Reign Supreme (Que la fête commence..., 1975), The Judge and the Assassin (Le Juge et l'assassin, 1976), Beatrice (La Passion Béatrice, 1987), Revenge of the Musketeers (La Fille de d'Artagnan, 1994), and The Princess of Montpensier (La Princesse de Montpensier, 2010), were commended for their attention to detail and their immersion in often bawdy worlds, but they also tended to foreground narratives in which the personal is linked with a wider story of history and in which the hypocrisy of state institutions - or the instruments of the state-is exposed. Invariably, as a child of the Libération, Tavernier frequently turned to the subject of the wars through which he had lived, namely the Second World War (in Safe Conduct (Laissez-passer, 2002), which probed the impact the war had on the film industry, and the "war that had no name", the Algerian war (the subject of his 1992 documentary, La Guerre sans nom, which he made in collaboration with historian Patrick Rotman and which, as Stephen Hay observes, offers us "a kaleidoscope of divergent memories" (127)). However, it was the war so insistently commemorated in the monuments that dominate every city, town and village in France that appears to have sparked particular fascination, as screenwriter Jean Cosmos noted: "the climate of the 1914-1918 war was something which haunted Bertrand; this conflict which people were beginning to forget, and which had been pushed into the background by another one. He is really searching for his personal memory, but also - and very much so-the collective memory" (qtd. in Hay 179). ${ }^{3}$

Captain Conan (Capitaine Conan, 1996), set on the less documented fronts of Macedonia and Romania, centres on the impact that war, and adherence to military codes, might have on the individual, while Life and Nothing But explores the tendency in historiography and in an "Industry of Commemoration" to privilege certain narratives to the exclusion of others. It follows a search by a wealthy woman (Sabine Azéma) for her husband, assumed to have been killed in the last days of the war. In her quest, she visits site after site, trawling through the neatly labelled effects collected from corpses strewn over pockmarked landscapes, in an effort to ascertain her husband's fate. Her personal search yields no corpse, only a hidden personal history (he was "engaged" to another woman). Her futile efforts are mirrored by those of the Major (played by Noiret), tasked with imposing a semblance of order on the chaos that war has brought. He initially believes that enumerating the dead and liaising with families to identify remains will make some difference, will demonstrate to the State, to a collective society, the individual cost of war and will ensure that the memory of it - or rather, 
memories of it - are preserved and lessons are learned. As he soon comes to realise, however, the state is indifferent, concerned only with privileging narratives of victory (in which a hundred dead French soldiers is a triumph in a battle that costs the Germans two hundred), and erecting generic obelisks, friezes and monuments that are visible but empty signifiers in a culture respectful only of a sanitised view of history.

Tavernier's preoccupation with memory and with "sites of memory" aligns him with many of the most influential postwar commentators and philosophers-Pierre Nora and his exploration of Les Lieux de memoire seems especially relevant-and with the filmmakers whose work is explored by the authors in this Issue.

Tavernier's concern with geographical sites invested with meaning, and his aspiration to cultivate a viewer that is actively engaged with history and its representations, also informs Alexander Kluge and Peter Schamoni's 1961 film, Brutality in Stone (Brutalität in Stein), reappraised by Frances Guerin in "Re-presenting Histories: Documentary Film and Architectural Ruins in Brutality in Stone". She assesses the film in light of recent scholarship on the architectural ruin and within a contemporary context in which the immediate experience of the Third Reich has given way to ever-more complex representations of it, necessarily inflected by the events and shifting critical discourse within German society (and cinema) since its fall. As she notes, in this (and in other work), Kluge's "insistence on making history conscious in the present" (14), to reveal the "multiple truths of history" (25), is expressed through a visually innovative formal style that weaves past and present, sound and image, archival images and present-day filming, to produce a dense, sometimes disorientating encounter with a locale that bears the imprint, both of political ambition and ideological certainty, and a reconfiguration wrought by the passage of time and Nature's inevitable dominance (as per Georg Simmel's conceptualisation).

Brutality in Stone has attracted considerable critical attention over the years, with Eric Rentschler's 1990 reading being especially influential, but Guerin argues that it continues to have significance for a contemporary Germany still struggling to come to terms with a past whose "value is rapidly changing" (14). In contrast to a certain tendency to render the ruin in aesthetically pleasing or nostalgic terms, she suggests that Klamoni and Kluge's film strives to "reinstate the historical power of architectural ruins" and-most pertinently for today's viewer- "consciously encourage civic engagement of the site, not idolisation of the past" (14). The result is the Reichsparteitagsgelände visually rendered as a "conglomeration of fragmented ruined surfaces, rather than as an oneiric symbol of an authoritarian regime" (15). Though the film predates his theory, Michael Rothberg's concept of "multidirectional pasts" seems especially relevant here: only when texts (or sites) become recontextualised, repurposed, and when new perspectives are allowed to emerge from the margins, can we arrive at a more complex understanding of the past, of memory and of trauma. Intrinsic to this project, and core to the film's continued relevance, is its insistence on the need for "the spectator to take responsibility for the continued interpretation and understanding of history" (28).

As Guerin delineates, Brutality in Stone presents us with a particular site that has been reconfigured by the passing of time and by the filmmaker's aesthetic. In "Non-Sites of Memory": Poland in Claude Lanzmann's Shoah Outtakes", Sue Vice and Dominic Williams investigate the significance of a number of locations filmed for Lanzmann's nine-hour documentary, released in 1985. More precisely, they consider a selection of the outtakeswhich run to a total of 220 hours - filmed by Lanzmann in a way that renders their locations featureless, even banal, "non-sites of memory" (35), in the director's own words. Lacking the 
expected details (such as shots of memorials), that would "expose" meaning within the frame, the location footage of the outtakes works in an associative way, building connections and juxtaposing spatially distant sites to elucidate history's repetitions and elisions. Vice and Williams cite one example of Lanzmann's palimpsestic strategy: a shot of the barbed wire fence at the Majdanek death camp, filmed in the 1970s, followed by glimpses of the crematorium chimney, is juxtaposed with a shot of the communist-era apartment blocks of the nearby city, reminding the viewer of how embedded the camp was in the banal surroundings of the town of Majdanek of the 1940s and the city of the 1970s. Lanzmann's palimpsestic approach here mirrors that of Kluge and Schlamoni in their layering of footage and of sound, as well as Tavernier's (the latter's executed in a less formally experimental mode). These are aesthetic approaches that require active visual and intellectual engagement: in the case of Shoah's outtakes, the viewer is denied the directive aids, such as explanatory voiceovers and eye-witness accounts, that are found in the film itself. Instead, as the authors note, absence or occasional "fleeting" glimpses of the monuments of "official recall", become the generators of meaning in the outtakes, a reminder of "genocidal history" (39).

As with many filmmakers of his generation, Tavernier and Marcel Ophüls among them, Lanzmann has tended to approach the idea of a coherent collective memory-a concept most famously expounded upon by Maurice Halbwachs in his influential thesis, Les Cadres sociaux de la mémoire - with some scepticism. Instead, Lanzmann views memory as being as much about making present a sense of absence, of "articulating" (retaining) the silences. As such, the authors note, a link may be made between this conceptualisation of memory and the manner in which he films the sites of the outtakes: both are "scarred", manifesting absences and gaps, eschewing visual signifiers of "official" commemorations of the Holocaust. As noted earlier in this Editorial, present day sites of human habitation often contain visual manifestations of traumatic historical events within their landscapes, reminding us of Halbwachs's observation that collective memory emerges and evolves within a "spatial framework" (6). Vice and William offer a new take on this phenomenon in their analysis of Lanzmann's outtake footage of the modern (1970s) city of Łódź which, they suggest, "invites us to recall a murderous history through everyday settings" (39). Again, the outtakes require active participation by the viewer, here tasked with identifying "the presence of the past in what seems to be an unremarkable cityscape" and participating in Lanzmann's elaboration of spatial memory (39). As the authors note, easily identified visual signifiers of the past (such as monuments) are not prioritised; instead, the outtakes present more allusive, imagistic details, ones that seem to replicate the ebbing patterns of "condensation and displacement" intrinsic to memory (39). The marginality of the outtakes, which were the last of Lanzmann's footage to be digitised and made available for researchers, reminds us, too, of the fluidity - the patterns of concealment and resurfacing - that underpin memory processes and the recounting of historical narratives.

Both Brutality in Stone and Shoah are preoccupied with the temporality and spatiality of memory. These also form the central threads that run through Elzbieta Buslowska's essay, "Silent (Un)Becoming Song: Poetic Adventures in History, Memory and Identity in Papusza and Song of Granite". She offers an experimental (and experiential) reading of two rich explorations of identity, memory and being: Pat Collins's poetical excursion into the life of the sean-nós singer Joe Heaney, and Joanna Kos-Krauze and Krzysztof Krauze's evocative portrait of the Romani singer and poet Bronislawa Wajs, more commonly known as Papusza. As Buslowska notes, both subjects are "solitary wonderers 'haunted' by their gifts. They are present and absent, passive and remote in their essential unknowability and their strangely orphaned singing. They move as if by something outside themselves" (64-5). 
Although each film offers an intimate portrait of it subject, neither can be seen to adhere to the patterns of linear narrative and structures of spectatorial address that characterise more conventional "biopics". Instead, in an audio-visual exploration that seems to mirror both the polarities of memory itself-erasure/manifestation; recollecting/forgetting - and its collage effect, the viewer is granted access to the subjects in an elusive, abstract mode. What is given to us is a sense of identity, a series of encounters with time and space, and an allusive locating of the subjects within their respective cultures.

Aleida Assmann has observed that, "[w]hen thinking about memory, we must start with forgetting. The dynamics of individual memory consists in a perpetual interaction between remembering and forgetting" (97). As Buslowska suggests, the formal strategies and, more broadly, the creative imagining that underpins these films, works to sculpt a kind of "cinematic memory - forgetting where the archive rejects the unifying practice of the past's one vision" (56). They do so by an innovative use of sound and image that includes recreations, archival footage, performances and long takes of landscape in Song of Granite and, in Papusza, rich black-and-white visuals overlayered with the sounds of poems being recited and music being performed. The adventurousness of the formal technique is complemented by an openness to depicting "different aesthetic and geographical territories" and "blurring the lines between documentary and biographical drama" (56).

Underpinning Buslowska's reading of the films - a response to "affective rather than textural terrains of the film experience" (57) — is a theoretical framework that invokes concepts derived from Maurice Blanchot (in particular, his concept of "disaster") and Gilles Deleuze/Felix Guattari (their conceptualisation of the refrain, as a navigation between home/unknown territories). As the author delineates, the refrain is an elusive force, from the margins of time and space, and capable of setting forth "encounter-events [that] deterritorialise the sense of chronological time, action and History in favour of nonsonorous and imperceptible forces, duration and intensity" (59). These encounters are experienced by the viewer through the filmmakers' blending of archive and imagined events, which blur the lines between "fact" and "fiction", and which cross time and space. Framed within a Deleuzian context, Buslowska suggests that in their eschewal of linear narratives and in the intensity (aural; visual) of their landscapes, the films grant us a "sense of memory" and access to an "insistent sensation of a homeland that belongs to nowhere and no one" (61). They invite us to contemplate the possibility of the creation of new worlds and intuitive encounters, and to reconfigure our navigation through — and understanding of — memory and histories.

Navigating history (cultural, generational, political) through the prism of memory and cinema is at the core of Davy Chou's film Golden Slumbers, which is explored by Marie Krämer in her essay, "In Search of a Lost Cinema: Cinephilia and Multidirectional Moving Image Memory in Golden Slumbers (Davy Chou, 2012)". Applying Michael Rothberg's influential intervention in memory studies and his positing of memory as "subject to ongoing negotiation, cross-referencing, and borrowing; as productive and not privative" (3), Krämer traces how cinephilia may be "reimagined as a multidirectional moving image memory culture" (72). As such, it works on several levels: from excavating the archives in search of forgotten films or censored productions, and cataloguing and compiling films for exhibition, to drawing on - in ways allusive or explicit - existing film material to shape new creative works. In his Variety tribute to Bertrand Tavernier, Thierry Frémaux, head of the Institut Lumière, observed that the passion that drives the cinephile is a "love of films as war weapons". For Davy Chou, cinephilia is a weapon to counter potential losses of film heritage and of cultural memory. 
Noting Aleida Assmann's writings on archives as repositories working against passive and active forgetting, Krämer maps the emergence of cinephilia in post-First World War France. As she observes, the desire to preserve a film heritage, even then under threat of destruction, was a recognition of the fragility of the cultural artefacts that contribute so significantly to the shaping of collective memory (the theorisation of which by Halbwachs emerges almost concomitantly with ideas of film heritage). Cinephilia is driven by a passion to retrieve, preserve and share, but simultaneously haunted by an awareness that it may already be too late for some films. As such, it mirrors more broadly the patterns of memory: of the acts of forgetting and recalling, and of cataloguing and curating, that are core to individual and collective navigations through (and presentations of) memory. Citing the work of Thomas Elsaesser on cinephilia, and Svetlana Boym on reflective nostalgia, Krämer notes that the cinephile can play a crucial role in collecting and curating individual memories that, in turn, shape an awareness of a shared cultural heritage. This seems especially important - and urgent - in the case of the Cambodian film culture, traces and memories of which form the subject of Chou's film. If cinephilia and the emergence of the concept of film heritage responded to a fear that the artefacts of cultural memory were in danger of being lost in the post-First World War context, the case of a film culture all but wiped out by a genocidal political regime, the Khmer Rouge, presents the cinephile/filmmaker with some similar, but also more complex, issues. At the heart of the creative work that Chou sculpts is a sense of profound loss and trauma. Most obviously, this is related to the enormity of the Cambodian genocide, but Chou is especially interested in tracing the loss of the creative: of the artists and intellectuals annihilated by the Khmer Rouge regime and the hundreds of films destroyed (wilfully; or sometimes through neglect). Yet, as Krämer argues, the devastating losses of the past can be counteracted by creative work in the present: by a filmmaker committed to "tracing the traces", through interviews with filmgoers who retained their own archives - in their memory banks and in the film ephemera they retained - of the cinema of Cambodia. As Golden Slumbers explores, the film culture that initially seems so irretrievable, so absent, can in fact be found in the memories shared and in the old songs, often derived from "lost" films, that continue to be performed, made present. While Krämer notes the influence that French/European tradition of cinephilia (expressed in viewing/writing and in creative work by Truffaut and Bertolucci) has had on Chou, she argues that in his references to styles and modes from Cambodian film productions he embraces a cinephilia that "serves as a mediator not only between different generations, but also between different times, places, cultures, and audiences" (80).

As has been noted in this Editorial and across many of the articles that form this Issue, memory is often aligned with, and triggered by, specific physical sites. Krämer considers the importance of one particular site, the Hemakcheat Cinema, filmed by Chou in an evocative style that conveys a tangible sense of the contemporary place - a slum in which only sparse remnants of the building are visible - and that recalls one of the European cinema's most nostalgic celebrations of the cinema site as site of memory, that of the Paradiso of Giuseppe Tornatore's Cinema Paradiso. Less literal than Tornatore in his approach, here Chou offers us a creative reimagining, an act of memory work, of a lost site and of an elusive film heritage whose status is equally precarious. As Krämer delineates, while Tornatore appears to view the Paradiso as a remnant of a past that must be left behind by his central protagonist (to remember only to forget), Chou retains some hope that Cambodian's cultural heritage can be retrieved, catalogued and curated through cross-generational collaborations, even as the physical site of the Hemakcheat is consigned to dust. Chou's cinephilia - to return to Frémaux's tribute to Tavernier - is of a sort not lost in regressive nostalgia, then, but one committed to a future in which film are weapons in an arsenal of preservation and creation. 
Creative work that entails acts of excavation, of the memories of marginalised or silenced individuals and communities, is under consideration in an analysis of two artworks that employ new, participatory technologies. In "Queering Cultural Memory Through Technology: Transitional Spaces in AR and VR", Maud Ceuterick explores how memory can be retrieved and experienced using the tools of Augmented Reality and Virtual Reality. Framing her case studies within theorisations of individual and collective memory from a range of scholars - including Halbwachs, Aleida Assmann, Anna Green and Jan Assmann-and drawing on Sara Ahmed's interventions in the field of spatial memory, she traces how Chez Moi (Caitlin Fisher and Tony Vieira, 2014) and Queerskins: Ark (Illja Szilak, 2020) reclaim suppressed or neglected narratives of marginalised subjects. As she argues, these reclamations serve as acts of empowerment, ones that "queer" the archive and that answer Aleida Assmann's call for scholars and practitioners to produce work that "retrieves lost objects and defunct information from a distant past, forging an important return path from cultural forgetting to cultural memory" (qtd. in Ceuterick 91). The need for such creative productions bears out Susannah Radstone's observation that memory is an act, a creative work, "shaped by diverse narratives and genres and replete with absences, silences, condensations and displacements that were related, in complex ways, to the dialogic moment of their telling" (11).

Memory, according to Richard Terdiman, has the "capacity to recollect and to restore the alternative discourses the dominant would simply bleach out and forget. Memory, then, is inherently contestatory" (20). In the artworks under examination here, the act of creation is not confined to the practitioner but entails contributions - that may influence the "narrative" - by the viewer. As Ceuterick delineates, the technologies of AR and VR open up unimagined possibilities for memory retrieval and viewer empowerment; for the restoration, with colour and movement, of the alternative discourses and experiences that may have been excised or "bleached" out. Ceuterick also examines the spatial and temporal implications for such projects of memory retrieval using AR and VR, noting that both work "by physically engaging the viewer in embodied experiences of individual queer memories established in 'real' contexts" present us with new "spaces for queer embodiment and imagination" (91). In Marie Krämer's essay on Golden Slumbers she notes how Chou emphasises the important role that crossgenerational collaboration - relating memories, receiving memories - can play in the retrieval and restoration of film culture. Ceuterick, too, points to the exciting cross-generational possibilities offered by the application of new technologies to the retrieval of marginalised memories and narratives. If the relating of a film memory or the singing of a song by an elderly Cambodian has the potential to forge new creative paths for a younger generation in Golden Slumbers, the new technologies of "AR and VR have the potential to transmit personal memory in an embodied way that is akin to how memory is transmitted between generations" (92).

Ceuterick, like many of the authors featured in this Issue, is concerned with works that excavate hidden histories, that bring to light, in the most embodied way, the memories of those previously consigned to the darkness of "an" imagining of a collective culture. As the authors of this Issue of Alphaville have explored, mining the archives - of memory; of official versions and curations of heritage - and bringing to the surface the memories and histories of those on the margins, are acts of restoration and of creation. Such acts inspired Tavernier in his seven decades as filmmaker, writer, intellectual, preservationist and cinephile. They can be detected, too, in the work of younger generations of filmmakers, among them Tadhg O'Sullivan, who features in the podcast of this Issue. His essay films are driven by a profound intellectual curiosity, inviting the viewer to undertake a journey of discovery that will illuminate and move, and perhaps inspire them to embark on journeys of their own. The palimpsestic approach O'Sullivan adopts is evidenced, not only by a layering of textual references (dizzying in their 
eclecticism) and film forms (recreations; archival material; surveillance footage), but in his audiovisual landscapes, which have the sensory texture of memory.

While the focus of this Editorial has been on memoralising the work of a filmmaker who made seminal interventions in the ongoing critical debate concerning memory and history, and on presenting overviews of five articles concerned with the theme of memory in film, I would like to end it by directing the reader to the dossier, on "Cinema and Memory", that also follows. Edited by Pierluigi Ercole, Daniela Treveri-Gennari and Lies Van de Vijver, it showcases scholarship that complements the work of the authors featured in the first part of the Issue. Here, the focus continues to be on memory, but with a particular emphasis on the impact that specific cinema sites, and their geographical locations, had on shaping cinemagoing memories (Agar; Roaro; Gil-Marino et al.); on tracing the influence that discrete film texts may have had in the formation of individual and collective identities (Terrill; Gil-Marino); and in delineating the challenges of archiving and digitising cinema memories (Agar; McDowell and Nissen). In the case studies by Agar and McDowell and Nissen they argue for the importance of creating accessible and "open" archives that adopt a "history from below" approach. There seems little doubt that Bertrand Tavernier would have approved of such an endeavour.

\section{Acknowledgement}

The editor would like to thank all the authors that contributed to this Issue and special thanks go to the peer reviewers who gave so generously of their time and expertise.

\section{Notes}

${ }^{1}$ Tavernier's father, René, was a writer, a political activist and the editor of the literary journal, Confluences. He and his wife sheltered poet Louis Aragon during the war.

${ }^{2}$ Uncomfortable truths, such as the discrepancy between Jean Renoir's films, which espoused humanistic values and signalled an alignment with the Left and/or the values of the Resistance, and Renoir's personal correspondence, in which he showed willingness to cooperate with Vichy, are explored by Tavernier in A Journey Through French Cinema.

3 As his close friend Volker Schlöndorff noted in his tribute to Tavernier: "He kept coming back to the war - not the popular, photogenic Second World War but the dirty first one, which had traumatized France; he went back to the mud and the trenches, not more than 200 miles from Paris (Life and Nothing Else, Captain Conan)." 


\section{References}

Assmann, Aledia. "Canon and Archive." Cultural Memory Studies: An Introduction, edited by Astrid Erll and Ansgar Nünning, Walter de Gruyter, 2008, pp. 97-109, DOI: https://doi.org/10.1515/9783110207262.0.1.

Beatrice [La passion de Béatrice]. Directed by Bertrand Tavernier, Cléa Productions, 1987.

"Belzec." Directed by Claude Lanzmann, Claude Lanzmann Shoah Collection, USHMM, 1985, collections.ushmm.org/search/catalog/irn1005189.

Brutality in Stone [Brutalität in Stein]. Directed by Alexander Kluge and Peter Schamoni, Alexander Kluge Filmproduktion, 1961.

Boym, Svetlana. The Future of Nostalgia. Basic Books, 2001.

Buslowska, Elzbieta. "Silent (Un)Becoming Song: Poetic Adventures in History, Memory and Identity in Papusza and Song of Granite." Alphaville: Journal of Film and Screen Media, no. 21, 2021, pp. 55-71, DOI: https://doi.org/10.33178/alpha.21.03.

Capitaine Conan [Captain Conan]. Directed by Bertrand Tavernier, Canal+, 1996.

Ceuterick, Maud. "Queering Cultural Memory Through Technology: Transitional Spaces in AR and VR.” Alphaville: Journal of Film and Screen Media, no. 21, 2021, pp. 89-110, DOI: https://doi.org/10.33178/alpha.21.05.

Chez Moi. Created by Caitlin Fisher and Tony Vieira, Video Walk, www.queerstory.ca/project/chez-moi, 2014.

Cinema Paradiso [Nuovo Cinema Paradiso]. Directed by Giuseppe Tornatore, Les Films Ariane, 1989.

The Clockmaker of St. Paul [L'Horloger de Saint-Paul]. Directed by Bertrand Tavernier, Lira Films, 1974.

Daddy Nostalgia [Daddy Nostalgie/These Foolish Things]. Directed by Bertrand Tavernier, Cléa Productions, 1990.

Elsaesser, Thomas. "Über den Nutzen der Enttäuschung: Filmkritik zwischen Cinephilie und Nekrophilie." Filmkritik heute: Bestandsaufnahmen und Perspektiven, edited by Irmbert Schenk, Schüren, 1998, pp. 91-114.

---. "Cinephilia or the Uses of Disenchantment." Cinephilia: Movies, Love and Memory, edited by Marijke de Valck and Malte Hagener, Amsterdam UP, 2005, pp. 27-44, DOI: https://doi.org/10.25969/mediarep/11988.

Frémaux, Thierry. "Cannes Director Thierry Frémaux Remembers Bertrand Tavernier: 'He Would Push You to Surpass Yourself'." Variety.com, 31 Mar. 2021, variety.com/2021/film/obituaries-people-news/thierry-fremaux-bertrand-tavernierinstitut-lumiere-1234941167. 
Golden Slumbers [Le Sommeil d'or]. Directed by Davy Chou, Vycky Films, 2011.

Guerin, Frances. "Re-presenting Histories: Documentary Film and Architectural Ruins in Brutality in Stone." Alphaville: Journal of Film and Screen Media, no. 21, 2021, pp. 13-34, DOI: https://doi.org/10.33178/alpha.21.01.

La Guerre sans nom. Directed by Bertrand Tavernier, GMT Productions, 1992.

Halbwachs, Maurice. Les Cadres sociaux de la mémoire. Alcan, 1925.

Hay, Stephen. Bertrand Tavernier: The Film-maker of Lyon. I.B. Tauris, 2000.

A Journey Through French Cinema [Voyage à travers le cinéma français]. Directed by Bertrand Tavernier, Little Bear, 2016.

The Judge and the Assassin [Le Juge et l'assassin]. Directed by Bertrand Tavernier, Lira Film, 1976.

Krämer, Marie. "In Search of a Lost Cinema: Cinephilia and Multidirectional Moving Image Memory in Golden Slumbers (Davy Chou, 2012)." Alphaville: Journal of Film and Screen Media, no. 21, 2021, pp. 72-88, DOI: https://doi.org/10.33178/alpha.21.04.

Let Joy Reign Supreme [Que la fête commence...]. Directed by Bertrand Tavernier, Fildebroc, 1975.

“Łódź.” Directed by Claude Lanzmann, 1979, Claude Lanzmann Shoah Collection, USHMM, 1985, collections.ushmm.org/search/catalog/irn1005222.

"Lublin and Majdanek.” Directed by Claude Lanzmann, 1979-1981, Claude Lanzmann Shoah Collection, USHMM, 1985, collections.ushmm.org/search/catalog/irn1005224.

L.627. Directed by Bertrand Tavernier, Canal+, 1992.

Nora, Pierre. Realms of Memory: Rethinking the French Past. Translated by Arthur Goldhammer. Johns Hopkins UP, 1997.

Papusza [Doll]. Directed by Joanna Kos-Krauze and Krzysztof Krauze, Argomedia Productions, 2013.

The Princess of Montpensier [La Princesse de Montpensier]. Directed by Bertrand Tavernier, Paradis Films, 2010.

Queerskins: Ark. Crated by Illya Szilak and Cyril Tsiboulski, Cloudred, 2018.

Radstone, Susannah. "Working with Memory: An Introduction". Memory and Methodology, edited by Susannah Radstone, Bloomsbury, 2010, pp. 1-24. DOI: https://doi.org/10.5040/9781474215251.

Rentschler, Eric. "Remembering Not to Forget: A Retrospective Reading of Kluge's Brutality in Stone." New German Critique, vol. 49, Winter 1990, pp. 23-41, DOI: https://doi.org/10.2307/488372. 
Revenge of the Musketeers [La Fille de d'Artagnan]. Directed by Bertrand Tavernier, Canal+, 1994.

Rothberg, Michael. Multidirectional Memory: Remembering the Holocaust in the Age of Decolonization. Stanford UP, 2009, DOI: https://doi.org/10.1515/9780804783330.

'Round Midnight. Directed by Bertrand Tavernier, Little Bear, 1986.

Safe Conduct [Laissez-passer]. Directed by Bertrand Tavernier, France 2 Cinéma, 2002.

Schlöndorf, Volker. "My Friend Bertrand." Criterion.com, 8 Apr. 2021, https://www.criterion.com/current/posts/7349-my-friend-bertrand.

Simmel, Georg. "The Ruin.” The Hudson Review, vol. 11, no. 3, Autumn 1958, pp. 371-85, DOI: https://doi.org/10.2307/3848614.

Song of Granite. Directed by Pat Collins. Amérique Film, 2017.

A Sunday in the Country [Un Dimanche à la campagne]. Directed by Bertrand Tavernier, Films A2, 1984.

Terdiman, Richard. Present Past: Modernity and the Memory Crisis. Cornell UP, 1993. DOI: https://doi.org/10.7591/9781501717604.

Vice, Sue, and Dominic Williams. "Non-sites of Memory": Poland in Claude Lanzmann's Shoah Outtakes." Alphaville: Journal of Film and Screen Media, no. 21, 2021, pp. 3554, DOI: https://doi.org/10.33178/alpha.21.02.

La Vie et rien d'autre [Life and Nothing But]. Directed by Bertrand Tavernier, Hachette Première, 1989.

\section{Suggested Citation}

Young, Gwenda. "Mining Memories: New Explorations in Cinema, Memory and the Past." Editorial. Alphaville: Journal of Film and Screen Media, no. 21, 2021, pp. 1-12, DOI: https://doi.org/10.33178/alpha.21.00.

Gwenda Young lectures in film studies at University College Cork. She has published articles on American cinema in journals and edited collections and has coedited two books (Amateur Filmmaking, with Laura Rascaroli and Barry Monahan; and Molly Keane: Centenary Essays, with Eibhear Walshe). She is the author of a monograph on the life and work of American film director, Clarence Brown: Hollywood's Forgotten Master, UP Kentucky, 2018. She is principal investigator on the Creative Ireland/Cork County Council/UCC-funded project, Cork Movie Memories. The project, a collaboration with Daniel O'Connell (Lecturer in Filmmaking at UCC), investigates cinemagoing memories and histories of cinemas in Cork city and county, and includes a web archive (corkmoviememories), outreach activities such as oral history days, screenings and exhibitions, and a documentary Movie Memories (vimeo.com/285104414). 